Bożena Totwińska

Uniwersytet w Biatymstoku

\title{
Do Pedagogy Students Perceive Collaboration as Valuable?
}

Values are not poured into us like water from a bottle. We must choose them. Life proposes certain values, but whether he will perceive, understand, or cultivate them depends on man. ${ }^{1}$

This study describes how students of pedagogy perceive group collaboration. The first part of this study sets forth a theological introduction to the basic concept of collaboration and its significance with regard to contemporary culture and to the profession for which the youth who participated in this study are preparing. The second part provides an analysis of qualitative data obtained during this study. According to our findings, the majority of the candidate-participants preparing to enter the field of pedagogy perceive group collaboration as something advantageous that fosters their development. Group collaboration can be a way to enrich the humanistic values of education, including respect for and trust of another person, which are essential to build a community of learners. It is difficult to introduce these values into the education system, however, because institutions are often pressured to increase their quantitative rankings, improve their scores, and compete with each other.

Key words: pedagogical formation, student, group collaboration, school of learning.

$\overline{1}$ J. Tischner, Myśli wyszukane, (Cracow: Wydawnictwo Znak, 2001), 78. 


\section{Introduction}

This study aims to present an analysis of data that reveals how students of pedagogy perceive group collaboration. The word "collaboration" is usually used interchangeably with the word "cooperation." Strictly speaking, however, the two terms have different meanings. "Collaboration" occurs when "at least two people work alongside each other and perform individual tasks to achieve a socially useful and common aim." Cooperation is the basis for collaboration. Each form of collaboration involves cooperation. However, not every form of cooperation is the same as collaboration. People can cooperate when playing together, teaching, or even working. Strictly speaking, then, collaboration is one form of cooperation. ${ }^{4}$ According to Jan Borkowski, "cooperation is a common form of positive social interaction which consists of diverse behaviors and actions of specific social subjects (persons, groups, institutions) that have interdependent goals, values, and interests. The essence of cooperation-unlike rivalry-is the common pursuit of particular goals, the independent fulfillment of which seems difficult or impossible;" whereas "collaboration is a more perfect and developed form of cooperation. The bonds of collaboration connect two people who work together to achieve clearly defined, short-term or long-term tasks as well as identical goals."6

Over the years, many situations necessitate that people collaborate with each other. The issue of individual's participation in a group and his or her effectiveness in collaboratively completing the task is interdisciplinary. Collaborating in a group is a social skill that belongs to a group of skills known as soft skills, which pedagogues, sociologists, academics, and psychologists emphasize as necessary to flourish in the world. ${ }^{7}$ The ability to collaborate is an indispensable skill to possess

2 More information on group collaboration can be found in: B. Tołwińska, K. Borawska-Kalbarczyk, and A. Korzeniecka-Bondar, Wolę chodzić wtasna droga (?)-o potencjale budowania wspótpracy z perspektywy studentów na pograniczu polsko-biatoruskim. This publication is currently in press.

H. Czarniawski, Wspótdziałanie potrzeba czasu (Lublin: Norbertinum, 2002), 30 .

Ibid.

J. Borkowski, Podstawy psychologii społecznej (Warsaw: Elipsa, 2003), 124.

Ibid.

$7 \quad$ J. Borkowski, Podstawy; B. Kożusznik, Zachowania człowieka w organizacji (Warsaw: Polskie Wydawnictwo Ekonomiczne, 2011); and P. Smółka, Kompetencje społeczne: Metody pomiarui doskonalenia umiejętności interpersonalnych (Cracow: Wolters Kluwer, 2008). 
in the modern world, not only because of its measurable benefits (e.g. organization), but also because of the value of teamwork and how it enables personal and social development (which will be discussed below).

The Polska 2050 [Poland 2050] report indicates that one of Poland's priorities is to reduce the divide between its civilization and the civilizations of other developed countries in the European Union. In order to achieve this end, it is necessary to fulfill many conditions, one of the most important of which is that: "Polish society must work much more toward mastering its capacity to work as a group without losing its individual creativity." 8 A successful vision of the future requires, for example, a modern educational system that is capable of modifying the cultural system. ${ }^{9}$ As Wanda Dróżka writes: "This involves an increasing realization of the need to (re)build in and through schools social solidarity and cultural identity, which have been lost in the highly individualized and alienating sense of community in today's world, while not neglecting individual needs and individuality." 10

In a society of individuals ${ }^{11}$ that is dominated by the market, young people learn to compete and concentrate on their own goals to achieve the best possible position. However, such an attitude subsequently endangers their welfare and often prevents their development. ${ }^{12}$ Over time, people have substantially changed how they perceive work. Today, people believe that efficiency must increase and that economic growth means progress. For this reason, Charles Handy's words written more than 15 years ago in his book The Age of Paradox, "for many life has become a struggle, and for the most part—a paradox," 13 are

$8 \quad$ KomitetPrognoz"Polska2000Plus,"RaportPolska2050(Warsaw:PolskaAkademia Nauk,2011), 88, http://rp2050.czasopisma.pan.pl/index.php?option=comconten t\&view $=$ article\&id=271:raport-polska-2050\&catid=103: wydania\&Itemid $=228$ (Accessed 09.15.2017).

Ibid.

W.Dróżka, “'Jak pokonać siłą własną’? Relacje nauczyciele-uczniowie w świetle pamiętników nauczycieli," in Uczłowieczyć komunikację: Nauczyciel wobec ucznia w przestrzeni szkolnej, ed. H. Kwiatkowska (Cracow: Oficyna Wydawnicza "Impuls," 2015), 149.

N. Elias, "The Society of Individuals" in The Collected Works of Norbert Elias, Vol. 10, (Dublin: University College Dublin Press, 2010); M. Jacyno, Kultura indywidualizmu (Warsaw: Wydawnictwo Naukowe PWN, 2007).

D. Doliński, "Ciemna strona rywalizacji," in Przeglad psychologiczny, no. 41 (1998): 181-200.

Handy, Charles. The Age of Paradox. Boston: Harvard Business School Press, 1995. 
relevant to people's everyday lives and appear in scientific texts today. At this point in time, competition among individuals has made its way into different aspects of life; as such, it has become both unnecessary and harmful. Rather than working collaboratively with others, people are more motivated by the attractiveness of ensuring for themselves a better position by doing things independently in order to distinguish themselves among others. According to free market ideology, the person is perceived as an individual who competes with others in order to ensure his own interests. Consequently, education that is based on this ideology forms students to become consumers rather than independently thinking citizens who are interested in the communities in which they live. ${ }^{14}$

Educational institutions (schools, universities) are particularly important places where valuable group activities can be promoted. In these institutions, students learn good practices, especially through direct experience. For example, students participate in projects that require teamwork. In the process, students learn about and engage in cooperation. Such engagement meets their social needs and allows them to take on different roles. There are two different dimensions to group activities: work and social. The work dimension involves the roles necessary to complete specific tasks: encouraging the group to take on some challenge (the initiator), gathering information (the information gatherer and provider), giving advice on task performance (the adviser), improving the concept of the work (stylist), determining whether the group's best ideas should be taken into account (the critic), and mobilizing the group to move forward (the mobilizer). In turn, the social dimension involves rewarding the group members, encouraging their ideas (especially those who are shy), encouraging the particiants, ensuring that the work atmosphere is good, relieving tensions among members, and ensuring that certain individuals do not dominate the group's work. ${ }^{15}$

In order for individuals to cooperate effectively in a group, they must be aware of their limitations and of the basic principles of good

$14 \quad$ E. Potulicka, "Edukacja dla demokracji," in Wychowanie: Pojęcia, procesy, konteksty 2, eds. M. Dudzikowa and M. Czerepaniak-Walczak (Gdansk: Gdańskie Wydawnictwo Psychologiczne, 2007). More on this subject can be found in: B. Tołwińska, "Overcoming organizational silence-looking for opportunities to change school culture," in Selected Papers of the Association for Teacher Education in Europe. Spring Conference 2015, eds. L. Daniela and L. Rutka (Cambridge: Cambridge Scholars Publishing, 2016), 209-221.

15 C. K. Oyster, Grupy, trans A. Bezwińska-Walerjan (Poznan: Wydawnictwo Zysk i S-ka, 2002), 35-36. 
communication such as: sharing knowledge, giving each participant the possibility to freely express himself, showing interest in the views of others, and genuinely and attentively listening to others. The group should reflect on any ideas and differences of opinion; for, these very ideas and opinions can serve as a source of inspiration. ${ }^{16}$ By considering the variety of roles that people can play in a group as well as the opportunities that group members have to practice constructive communication during a collaborative group effort, it is clear that group collaboration in education is a means to help people develop the humanistic skills of respect for and trust in others.

However, not every group dynamic makes it more possible for individuals develop certain skills. For example, some groups function immaturely ${ }^{17}$ and defensively. ${ }^{18}$ As a result, the individuals that belong to this group, or the organizations under which the group functions, are unable to develop. People often criticize group activities because they can result in, for example, polarization, social loafing, and groupthink. ${ }^{19}$ In addition, B. F. Meeker includes conflicting aims among group members and improper decision-making patterns as sources of loss incurred by group tasks. ${ }^{20}$ In this sense, group activities exhibit the opposite of good decision-making, which is characterized by the rational consideration of all available information and opinions that enables different points of view to emerge and overcomes the illusion of correct unanimity. ${ }^{21}$

Studies reveal that researchers have observed that collaboration has a variety of benefits. For example, D. Doliński quotes many studies that argue that, among other things, collaboration facilitates intellectual development and the procurement of knowledge, promotes positive attitudes towards others, and drives the members' internal motivation

16 M. Płócińska and H. Rylke, Czas wspótpracy i czas zmian (Warsaw: WSiP, 2002), 79 .

17 S.Mills, "Kierowanie zespołami w procesie wprowadzania zmian," in Wspótczesne tendencjew kierowaniuzmianąedukacyjna, ed.D.Ekiert-Grabowska (WarsawRadom: Ministerstwo Edukacji Narodowej, Instytut Technologii Eksploatacji, 1997).

18 G.Bartkowiak, Psychologiawzarzadzaniu.Nowe spojrzenie(Poznan: Wydawnictwo Uniwersytetu Ekonomicznego w Poznaniu, 2010).

19 C. K. Oyster, Grupy, 185-186; B. Wojciszke, Psychologia społeczna (Warsaw: Wydawnictwo Naukowe Scholar, 2011), 467- 472.

20 B. F. Meeker, "Praca zespołowa: dylematy współpracy," in Procesy grupowe: Perspektywa socjologiczna, eds. J. Heidtman and K. Wysieńska (Warsaw: Wydawnictwo Naukowe SCHOLAR, 2013), 291.

$21 \quad$ B. Tołwińska, "Overcoming organizational." 
to work. ${ }^{22}$ Effective collaboration within a group enables individuals to conserve their individual resources-mainly time and energy; to share their knowledge and experience with each other; to elicit the (often hidden) talents of group members; to satisfy their need to be accepted and part of a group-both of which are powerful sources of motivation; to find better solutions, since a the solution that come from a synergistic group approach is better than a solution that comes from one individual. ${ }^{23}$ When working alone, individuals have only their own resources; when individuals work together in groups, however, a special kind of energy called "synergy" occurs. ${ }^{24}$ While synergy does not occur in every group, those groups in which it does occur are the most successful. Among the benefits of collaboration, B. Wojciszke includes "warming up" participants to a particular effort, perseverance through imitation, the use of unique skills, readiness to compensate for others' deficiencies, and mutual stimulation-all of which result in "a group knowledge that creates new and better quality." 25 Another benefit of collaboration is that, through it, individuals can participate in the creation of shared goods and the increase their social competence. ${ }^{26}$

Collaboration provides an individual with a chance to intensify his own development. If individuals find that completing tasks through collaboration is valuable, then they will willingly get involved in collaborative efforts and experience its benefits; in other words, they will not wait to collaborate only when they are required to do so and pretend to do so. How, therefore, do first-year pedagogy students understand collaboration? Are they focused on collaborating? And, what do they perceives as the benefits and difficulties of collaborating?

\section{Research Methods}

This article analyzes how first-year pedagogy students perceive group collaboration by addressing the following questions: How do

D. Doliński, "Ciemna strona."

H. Czarniawski, Wspótdziałanie, 22;D. Elsner,Doskonaleniekierowania placówka oświatową. Wokót nowych pojęć i znaczeń (Chorzow: Wydawnictwo Mentor, 1999), 139; M. Płócińska and H. Rylke, Czas wspótpracy, 70; B. Tołwińska, "Proaktywność i synergia w kulturze szkoły," Studia Pedagogiczne, no. 64, eds. M. Dudzikowa and S. Jaskulska (2011): 265-273.

See C.K. Oyster, Grupy, 193. Cattell discovered synergy in 1948 while observing the process of group communication. He defined synergy as a specific type of energy that arises between people who are communicating with each other.

B. Wojciszke, Psychologia, 464. 
students perceive collaboration? Do they see it as valuable? What determines students' engagement in collaborative group efforts? What difficulties do the students perceive in collaborating?

The study data was obtained via feedback from 76 first-year pedagogy students both while and after they participated in team projects related to their lectures from 2015-2016 and 2016-2017 school years. The data takes the form of quotations from students' statements. ${ }^{27}$ Their statements were subsequently analyzed qualitatively, and the data was sorted, encoded, and categorized. More specifically, students were presented with a specific educational problem to solve and then asked to work in groups in order to solve the problem. The student groups subsequently presented how they worked together to solve their problem to a forum and led a mini workshop on the skills related to topic of their specific project. To this end, participants each performed specific tasks that they independently planned and organized. Students had to refer to various sources to find information related to their specific tasks, choose which information to use, and, based on the information, design activities aimed at changing that practice. Each team completed their project in a different way; some teams worked on the initial phase of a project, while other teams took advantage of other sources of information and methods to present information. For example, one team made an amateur video recording of their interviews with school directors, teachers, parents, and students. The most important aspect of the project was that students work independently and they return to the group where they could share their results with others. The last part of their group collaboration involved reflecting on how the group accomplished the project, whether the goals that the team set were achieved, what the group found to be the most difficult and satisfying, and what the audience appreciated about the project and presentation. This final stage of the project caused the students the most difficulty.

After completing their respective projects, students freely described their experiences working as members of a team. The purpose of this study is to understand the way that students perceive teamwork-what they find interesting and important about it, since these very same students will themselves have to complete certain tasks or jobs by working collaboratively in groups after they graduate. For example, after completing their studies, pedagogy students will work for educational institutions or organizations, or they will create these institutions and

27 D. Kubinowski,Jakościowe Badania Pedagogiczne: Filozofia-Metodyka-Ewaluacja (Lublin: Wydawnictwo UMCS, 2011). 
organizations themselves. The question then arises: what will these students contribute to the schools and organizations for which they will one day work? How will their skills and values enrich their interpersonal relationships? Perhaps the students' feedback will reveal what aspects of a university education are important to consider and how students can take advantage of their studies to hone their ability to collaborate. These issues are of particular importance, particularly in light of the contemporary challenge for schools to become teaching organizations. $^{28}$

Miscellanea

\section{Study Results}

While working on their projects, students developed different types of skills, which will not be discussed in this study, since its purpose is to describe the students' experiences collaborating within the group.

In their statements, the students clearly expressed their desire to complete tasks through group collaboration more often. From the students' points of view, working together in a group is a good way to accomplish tasks. The majority of the youth perceived that there were many benefits of working in a group. Decidedly fewer students spoke about the negative aspects of group collaboration. Although fewer in number, these statements can be a source of inspiration for teachers (myself included) regarding what aspects of team projects to pay attention so that, at the same time, with essential knowledge, the youth can employ the win-win principle when working in teams ${ }^{29}$ and, thereby, most fully develop their collaborative skills. The students themselves perceived that, from a professional point of view, they will become a desirable "assets" in their future work. Here are some examples of the students' responses:

"Teamwork has allowed us to assimilate. When we expressed different points of view, our collaborative efforts made us discuss these issues, be open to each other's opinions, and come to a final decision together. I really liked the discussions because I could learn other people's points

Senge P.M., The Fifth Discipline: The Art and Practice of The Learning Organization (New York: Doubleday, 1990); M. Fullan, Change Forces: Probing the Depths of Educational Reform (London: Falmer Press, 1996); M. Fullan, Leading in a Culture of Change (San Francisco: Jossey-Bass, 2001); M. Fullan, The Moral Imperative of School Leadership (California: Corwin Press, 2003); E. Potulicka, "Paradygmat zmiany edukacyjnej Michaela Fullana," in Szkice z Teorii i Praktyki Zmiany Oświatowej (Poznan: ERUTITUS, 2001). 1989). 
of views and compare them to mine. This exercise will help me in the future. The lessons made me realize that I need to do everything in my power to take advantage of what I have learned and change for the better" (43). ${ }^{30}$

"I liked this type of activity very much. Each [project] could look like this" (8). "I could show my creativity. I am very happy with this project because I had the opportunity to participate in it. I consider this to be a very useful experience" (10). "I liked working on this project; we could coordinate with each other, spend time together, and learn teamwork. It would be useful to do this type of work more often so that we can practice teamwork" (42).

The students described the benefits of team collaboration as follows:

- it met the need to be part of a group

I really liked working on a team. I had the opportunity to collaborate with my fellow team members. It was a very positive experience (28).

- it "warmed up" participants to do their part and involved everyone

"Participating in group projects is a good motivation to be involved. We weren't just passive listeners; instead, we were involved and we learned through practice" (11). "I worked really well in a group; my colleagues and I worked together more; each of us had to do a different job, and, through this, we learned many things from each other. Each of us dedicated a lot of time to this project, was involved in what we did, and wanted to share our knowledge with the group. I realized like this teamwork because, thanks to it, we could consolidate our knowledge and work together" (16). "I believe that group projects are a good way to mobilize everyone; through it, each person could be involved" (21). "It provided us with an opportunity to perfect our own skills. It was satisfying and pleasant to work in a group. Each person did his part and was involved in the entire project" (26). "I liked working together in a group. We were able to get to know each other better and see how to collaborate. I like that we ourselves got to prepare the project. Each of us was able to contribute something, and we were motivated" (29). "What I liked about my team: we divided up the duties, helped each other out, shared out thoughts, and mobilized each other" (65).

- it conserved individual resources and helped participants practice better time management

"Looking from the perspective of another person, dividing the taskseach person focuses on that which he knows the best, and the terms are established at the end of each phase of the project" (70). "I worked really well in the group; each person contributed, and it was clear that

The students' testimonies are identified by the numbers in parenthesis. 
each person was involved. If someone among us didn't know something, then it was possible to ask for help" (20). "Time was organized better, and we didn't put off our respective parts until later" (72).

- sharing knowledge

"A group project was interesting; we could each choose the way; we were active, involved, could share our knowledge with the others, and show our strengths" (41). "Working in a group was great! Individual work is more difficult and boring. [...] When the group hung out, there was an adrenaline rush, and I experienced an amazing sense of satisfaction when I saw that other people liked our project and that they learned something from it" (45).

- the realization of strengths and overcoming weaknesses

"Working in a group reminded each of us what we are respectively good at. We learned to collaborate. Sometimes it was difficult, but we learned to respect the opinions and ideas of others. Some people were more motivated than others" (24). "I liked teamwork; it helps one to be less shy, speak in front of an audience, and this kind of task stimulates creativity" (18).

\section{- the development of communication skills}

"The possibility to work in a group develops and integrates human interaction. Each person could say something on a given topic and he wasn't judged" (33). "Working in a group was super! Working individually is more difficult and results in fewer ideas. When working in a group, there is greater variation and it is possible to learn more interesting things and to hear the opinions of others" (50). "I liked working in a group. It helped me to concentrate better on the subject. We were more into it, and group work inspires creativity. Working individually is boring and monotonous; there is no one else to help, and we have to rely on ourselves. When working in a group, we can learn how other people think" (52). "I worked really well in a group. We worked on the brainstorming method. Each person could say something without fearing that his idea would be ridiculed" (56). "I really liked working in a group. I think that we were able to work together very well. Each person had a chance to say something and share his opinion" (59). "This kind of work taught us how to listen to each other" (61). "It was interesting to listen to the group members exchange opinions" (62). "I could express my thoughts and views and also consult other group members about them" (63). "I liked working on my ability to listen and boldly express my opinions" (64). "I learned to listen closely to others, give others more freedom, and speak directly about my feelings" (69). "I learned to respect others and calmly express my own opinion. The atmosphere was friendly, and 
there was a sense of understanding and trust. We finished the work on time" (73).

In order to collaborate, it is necessary to reconcile individual aspirations and thoughts with the common good. Not every team was able to work together and create a win-win situation. This occurred when there was:

- lack of involvement

"Certain difficulties arose; not everyone was equally involved" (47). "Some participants placed the responsibility on others" (65). "One group worked really hard, while in another group some members did not do anything at all. Instead, they thought that the other group members would do their part for them" (66). "Some people did only what was absolutely necessary" (67). "Not everyone was equally involved, some group members were disinterested, others didn't meet the deadline, while other members became enemies" (76).

- poor time management

"Some people did not consider the ideas of all of the team members, while other members had a negative attitude toward each other. Some people were disorganized" (71) "It was not possible to trust $100 \%$ when one person took the leadership role and wanted to rule over everything. He attributed everything that the group did to himself" (75). "Some members did not turn in their work on time" (74). "One person failed to meet her deadlines and obligations. As a result, everything was chaotic and disorganized" (68).

"Collaboration also brought out the follow negative personality traits and behavior of some team members: greed, jealousy, manipulation, quarreling, problems, complaining" (73), "rivalry, and exploitation" (74).

\section{Discussion}

The youth directed their learning process within the course of their team projects. They planned and organized their work together, and, as many of the students testified, working on group projects was a very meaningful experience. Based on our analysis, students describe group collaboration not only as valuable, but also as beneficial to their individual development. When team work is based on the win-win principle,${ }^{31}$ participants reinforce constructive communication, speak freely, and, at the same time, see the another person's perspective, respect the opinions and ideas of others, overcome shyness, publicly

$31 \quad$ S. R. Covey, 7 Habits. 
express their own opinions, present their own ideas without fear of being mocked or ridiculed, motivate each other to act, learn from one another, discover their strengths and show them to others, and use their creativity. In the students' comments, it was clearly evident that communication within the group took place and was very important for the groups to succeed as a whole.

Some students found it difficult to collaborate as evident in their lack of involvement, time-mismanagement, and unfavorable personality traits. As the researchers in this study point out, social loafing is a widespread group labor deficit manifested in the fact that some members exert less effort and energy while simultaneously benefiting from the fruits of the work of others in the group. ${ }^{32}$ This results in lower group performance and diminished final outcomes. ${ }^{33}$ Social loafing occurs because of dispersion of responsibility and deindividuation, certain group participants put in less effort and feel less responsible for their share of the project because they feel that their contributions will go unrecognized and, consequently, remain anonymous. ${ }^{34}$ Important factors that can eliminate laziness are when a group understands the significance of its task as well as the group's importance to its members. When these values are high within a group, then its members will be socially diligent and increase their efforts to complete the group's tasks. ${ }^{35}$ In addition, trust among group members eliminates laziness because, when group members trust each other, they work more effectively. ${ }^{36}$

In this study, students stated that the skills that they learned during their group projects are relevant to their future work. After analyzing the students' responses, it is clear that young people expect to learn through collaboration. The study group was made up of first-year pedagogy students; therefore, for many of them, working on a team was a good way to meet and get to know new people and fulfill their need to be part of a group. Approaching this subject from another angle, it is worthwhile to take advantage of the beginning of students' education by offering them opportunities to participate in well-prepared team

Bibb Latane et. al studied and described this phenomenon in 1979. See B.F. Meeker, "Praca zespołowa," 292.

R. Brown, Group Processes: Dynamics Within and Between Groups (New Jersey: Basil Blackwell Inc., 1988), 158.

C.K. Oyster, Grupy, 191.

See Karau and Williams (1993) in R. Brown, Group Processes, 160; C.K. Oyster, Grupy, 191.

See Jackson Harkins in C.K. Oyster, Grupy, 192. 
projects and acquire positive teamwork experience. In this respect, within this analysis it is also important to consider those students who expressed difficulties working in a group. This feedback can help educators find better solutions to limit or eliminate social loafing, even though the number of social loafers within given groups was few.

The positive response of youth to cooperation is insufficient to fully understand this subject matter. Rather, it is a reason to reflect on the deeper problem, on which Eve Boncho's analyses shed light. As a participant in team research ${ }^{37}$ Eve Boncho has studied and dealt with peer relationships in, for example, student groups from different grade levels. According to Boncho's descriptions students were consistently characterized by the group to which they belong; they mutually accepted each other and count on each other for support (more often in academic situations than in difficult personal matters). These students reported having mediocre self-confidence. Given the nature of their collaborative project, they were unable to create a lasting community, and the group remained together only while it performed a particular task. As Boncho emphasized, school communities can flourish only if students experience a sense of community. If students who are educated in a system dominated by rankings, scores, and rivalry, then they will not be able to create school communities in the future. ${ }^{38}$

According to E. Bochno's research, this analysis demonstrates that the issue is a matter of transferring positive individual experiences of collaboration to practice as a permanent feature of school culture. Since research confirms that collaboration improves student learning, ${ }^{39}$ modern schools should strive to strengthen collaboration in pedagogical teams. Building teams of teachers who can work and learn together is a challenge today due to the established norms that teachers perform their work individually behind classroom doors, ${ }^{40}$ the pressure to achieve high educational outcomes scores and rankings, and the current societal trend to strive primarily for what will benefit oneself and exaggeratedly focusing on securing one's own position in the labor

37 Boncho is a member of a team working under the scientific direction of Professor Maria Dudzikowa.

38 E. Bochno, "Relacje rówieśnicze w szkołach różnego szczebla: dążenie do wspólnoty czy atomizacji?-głos w dyskusji," in Przyszłość: Świat-Europa-Polska, no. 1 (2013).

39 L. Stoll, R. Bolam, A. McMahon, M. Wallace, and S. Thomas, "Professional Learning Communities: A Review of the Literature," in Journal of Educational Change, no. 7 (2006), doi 10.1007/s10833-006-0001-8

40 A. Hildebrandt, "Koncepcja rozwoju organizacyjnego szkoły Pera Dalina," in Szkice $z$ teorii, ed. E. Potulicka (Poznan: ERUTITUS, 2001), 124. 
market. According to H. Kędzierska and M. Maciejewska's research, teachers feel like they must compete; they feel alone; they are afraid of losing their jobs; and even formally established teamwork within their workplaces does not create an educational community. ${ }^{41}$ Likewise, numerous researchers have identified that collaboration among pedagogues is difficult. ${ }^{42}$ For example, the teachers who participated in one of B. Zamorska's studies described an atmosphere of rivalry, jealousy, and even enmity at the school where they work. These teachers feel obliged to pretend that they are succeeding, when in reality they are individually accountable for certain outcomes (student's average grades, number of diplomas in competitions, etc.). Moreover, employees at this same school had stolen original ideas to make the school stand out at all costs..$^{43}$ In addition, in the context of the same research project, there was another school where teachers have been meeting as a team for a long time, and their collaboration is "directed at solving difficult problems, creating and realizing interesting educational ideas, providing mutual support (among teachers and students), and engaging in continued learning." ${ }^{44}$ These teachers experienced mutual openness, trust, and a sense of "togetherness." ${ }^{45}$ This study reveals how different the everyday experiences of teachers are. On the one hand, one school had a tense and destructive atmosphere, while the second school had a cooperative atmosphere. Similarly, students from the respective aforementioned schools were also completely different. In the first school, the best strategy for a teacher to survive is to build a metaphorical wall to separate her from her students, who should know who is in charge at the school. In the other school, however, teachers felt responsible for supporting their students, whose use the world of their students as the point of departure to help them understand their students' attitudes and to foster among teachers a sense of working

$41 \quad$ H. Kędzierska and M. Maciejewska, "Odpowiedzialny nauczyciel - (nie) odpowiedzialna wspólnota-co pomaga, a co przeszkadza w budowaniu nauczycielskich wspólnot praktyków," in Edukacjajako odpowiedź. Odpowiedzialni nauczyciele w zmieniajacym sięświecie, ed. G. Mazurkiewicz (Warsaw-Cracow: Wydawnictwo Uniwersytetu Jagiellońskiego, 2014), 89. I have written further about this topic in my article Teacher Team's Maturity as the Basis for a School of Learning, which is currently in press. 
together to help their students. Even more examples of these kinds of communities of learning exist. ${ }^{46}$

The students of pedagogy who took part in this study participated in an educational situation in which they could develop collaborative skills that will be useful to them in the future. As evidenced by their feedback, these students appreciated the relationships that they formed in the course of their group projects-relationships that they needed. Perhaps the students' positive experiences of collaboration will be a source of inspiration to them, such that they will want to apply their newly found knowledge to other areas of their lives. And perhaps, as future teachers themselves and for the good of their students, they will implement their skills in order to build lasting bonds among teachers involved in communities of learning in schools where they will one day teach. This undoubtedly depends on them and on the attitudes of the other teachers and directors, as evidenced above by the pedagogical group involved in B. Zamorska's studies. For, pragmatism rather than a sense of community and an attitude that favors one's own benefit rather than working together to strive for the common good are growing in commercialized schools subject to quantitative rankings. ${ }^{47}$

\section{WSPÓŁPRACA JAKO WARTOŚĆ W PERCEPCJI STUDENTÓW PEDAGOGIKI}

Celem tekstu jest opis sposobu postrzegania współpracy w grupie przez studentów pedagogiki. Struktura tekstu obejmuje dwie części. Pierwsza zawiera teoretyczne wprowadzenie w problematykę współpracy w podstawowym zakresie oraz uzasadnienie jej ważności w odniesieniu do współczesnego kontekstu kulturowego, a także specyfiki zawodu, do którego badana młodzież przygotowuje się. Druga część obejmuje prezentację jakościowej analizy danych. Wynika z niej, że wśród badanych kandydatów do zawodu pedagoga, dominujące jest postrzeganie współpracy w grupie, jako formy dającej wiele korzyści, sprzyjającej rozwojowi uczestników. Ta forma może być drogą do uobecniania w procesie edukacji wartości humanistycznych: szacunku i zaufania do drugiego człowieka, które są podstawą budowania uczących się wspólnot, jednak ich powstawanie jest bardzo utrudnione w systemie edukacji poddanej presji ilościowych rankingów, punktacji i rywalizacji.

Słowa kluczowe: kształcenie pedagogiczne, student, współpraca w grupie, szkoła ucząca się.

${ }_{46} \quad$ See B. Tołwińska, Teacher team's maturity.

47 E. Potulicka, "Edukacja dla demokracji." 


\section{Bibliography:}

1. Bartkowiak, G. Psychologia w Zarzadzaniu: Nowe Spojrzenie. Poznan: Wydawnictwo Uniwersytetu Ekonomicznego w Poznaniu, 2010.

2. Bochno, E. "Relacje rówieśnicze w szkołach różnego szczebla: dążenie do wspólnoty czy atomizacji?—głos w dyskusji." Przyszłość: Świat-EuropaPolska, no. 1 (2013): 119-125.

3. Borkowski, J. Podstawy psychologii społecznej. Warsaw: Elipsa, 2003.

4. Brown, R. Group Processes: Dynamics Within and Between Groups. New York: Basil Blackwell, 1988.

5. Covey, S. R. The 7 Habits of Highly Effective People. New York: Free Press, 1989.

6. Czarniawski, H. Wspótdziałanie potrzeba czasu. Lublin: Norbertinum, 2002.

7. Doliński, D. “Ciemna Strona Rywalizacji." In Przegląd Psychologiczny, no. 41 (1998): 181-200.

8. Dróżka, W. “'Jak pokonać siłą własną?’ Relacje nauczyciele-uczniowie w świetle pamiętników nauczycieli." In Uczłowieczyć Komunikację: Nauczyciel Wobec Ucznia w Przestrzeni Szkolnej. Edited by H. Kwiatkowska. Cracow: Oficyna Wydawnicza "Impuls," 2015.

9. Elias, N. "The Society of Individuals" in The Collected Works of Norbert Elias. Vol. 10. Dublin: University College Dublin Press, 2010.

10. Elsner, D. Doskonalenie kierowania placówka oświatową: Wokót nowych pojęć i znaczeń. Chorzow: Wydawnictwo Mentor, 1999.

11. Fullan, M. Change Forces: Probing the Depths of Educational Reform. London: Falmer Press, 1996.

12. Fullan, M. Leading in a Culture of Change. San Francisco: Jossey-Bass, 2001.

13. Fullan, M. The Moral Imperative of School Leadership. California: Corwin Press, 2003.

14. Handy, C. The Age of Paradox. Cambridge: Harvard Business School Press, 1995.

15. Hildebrandt, A. "Koncepcja rozwoju organizacyjnego szkoły Pera Dalina." In Szkice z teorii i praktyki zmiany oświatowej. Edited by E. Potulicka. Poznan: ERUTITUS, 2001.

16. Jacyno, M. Kultura indywidualizmu. Warsaw: Wydawnictwo Naukowe PWN, 2007.

17. Kędzierska, H. and M. Maciejewska. “Odpowiedzialny nauczyciel-(nie) odpowiedzialna wspólnota: co pomaga, a co przeszkadza w budowaniu nauczycielskich wspólnot praktyków." In Edukacja jako odpowiedź. Odpowiedzialni nauczyciele w zmieniającym się świecie. Edited by G. Mazurkiewicz. Warsaw-Cracow: Wydawnictwo Uniwersytetu Jagiellońskiego, 2014.

18. Komitet Prognoz "Polska 2000 Plus." Raport Polska 2050. Warsaw: Polska Akademia Nauk, 2011, 88, http://rp2050.czasopisma.pan.pl/ index.php? option $=$ comcontent $\&$ view $=$ article $\&$ id $=271$ :raport-polska-2050\&catid =103: wydania\&Itemid =228. (Accessed 09.15.2017).

19. Kożusznik, B. Zachowania człowieka w organizacji. Warsaw: Polskie Wydawnictwo Ekonomiczne, 2011. 
20. Kubinowski, D. Jakościowe badania pedagogiczne. Filozofia-MetodykaEwaluacja, Lublin: Wydawnictwo UMCS, 2011.

21. Meeker, B.F. "Praca zespołowa: dylematy współpracy." In Procesy grupowe. Perspektywa socjologiczna. Edited by J. Heidtman, K. Wysieńska. Warsaw: Wydawnictwo Naukowe SCHOLA, 2013.

22. Mills, S. "Kierowanie zespołami w procesie wprowadzania zmian." In Wspótczesne tendencje w kierowaniu zmiana edukacyjną. Edited by D. Ekiert-Grabowska. Warsaw-Radom: Ministerstwo Edukacji Narodowej, Instytut Technologii Eksploatacji, 1997.

23. Oyster, C. K. Grupy. Translated by A. Bezwińska-Walerjan. Poznan: Wydawnictwo Zysk i S-ka, 2002.

24. Płócińska, M., and H. Rylke. Czas wspótpracy i czas zmian. Warsaw: WSiP, 2002.

25. Potulicka, E. "Paradygmat zmiany edukacyjnej Michaela Fullana." In Szkice z teorii i praktyki zmiany oświatowej. Edited by E. Potulicka. Poznan: ERUTITUS, 2001.

26. Potulicka, E. "Edukacja dla demokracji." In Wychowanie. Pojęcia, procesy, konteksty 2. Edited by M. Dudzikowa and M. Czerepaniak-Walczak. Gdansk: Gdańskie Wydawnictwo Psychologiczne: 2007.

27. Senge, P. M. The Fifth Discipline: The Art and Practice of The Learning Organization. New York: Doubleday, 1990.

28. Smółka, P. Kompetencje społeczne: Metody pomiaru i doskonalenia umiejętności interpersonalnych. Cracow: Wolters Kluwer 2008.

29. Stoll, L. R.; A. Bolam, M. McMahon, and S. Thomas Wallace. "Professional Learning Communities: A Review of the Literature." In Journal of Educational Change, no. 7 (2006): 221-258. doi 10.1007/s10833-006-0001-8

30. Tischer, J. Myśli wyszukane. Cracow: Znak, 2001.

31. Tołwińska B. "Proaktywność i synergia w kulturze szkoły." Studia Pedagogiczne, no. 64. Edited by M. Dudzikowa and S. Jaskulska (2011): 265-273.

32. Tołwińska B. "Overcoming organizational silence-looking for opportunities to change school culture." In Selected Papers of the Association for Teacher Education in Europe. Spring Conference 2015. Edited by L. Daniela and L. Rutka. Cambridge: Cambridge Scholars Publishing, 2016.

33. Tołwińska B. (in press). Teacher Team's Maturity as the Basis for a Learning School.

34. Tołwińska, B., K. Borawska-Kalbarczyk, and A. Korzeniecka-Bondar. (in press). Wolę chodzić wtasna droga (?) - o potencjale budowania wspótpracy $z$ perspektywy studentów na pograniczu polsko-białoruskim.

35. Wojciszke, B. Psychologia spoteczna. Warsaw: Wydawnictwo Naukowe Scholar, 2011.

36. Zamorska, B. Nauczyciele. (Re)konstrukcje bycia-w-świecie edukacji. Wroclaw: Wydawnictwo Naukowe Dolnośląskiej Szkoły Wyższej, 2008. 